\title{
Reculturing schools in England: how 'cult' values in education policy discourse influence the construction of practitioner identities and work orientations
}

Agnieszka Bates

The imperative of continuous improvement has now become normative in education policy discourse, typically framed as setting 'aspirational' targets for pupil performance as a prerequisite for gaining competitive advantage in the global economy. In this context, teachers, leaders, teacher assistants and other practitioners working in schools across England have been under increasing pressure to raise standards. This paper focuses on how values are deployed in reculturing and regulating practitioners to develop identities and work orientations which are congruent with the policymakers' agendas. G. H. Mead's concept of 'cult' values illuminates the process of fostering homogeneity with the dominant policy discourse through an inclusion/exclusion dynamic. Interview data collected in two primary schools, revealed a significant convergence of practitioner discourse with policy objectives. Delivering improvement affects how practitioners talk about their work and see themselves as educators. The 'cult' of continuous improvement appears to inhibit a critical approach to the implementation of education policies by school practitioners in their everyday work.

Keywords: education policy; values; exclusion; continuous improvement; G. H. Mead

The context for this paper is the ongoing reform of the school system in England, aimed at pupil mastery of core subject knowledge and a 'firm grip' of basic numeracy and literacy skills (Department for Education [DfE], 2010, p. 66). To this end, successive government policies have utilised a regime of standards, pupil targets, school performance tables and inspections conducted by the Office for Standards in Education 
(Ofsted). Ofsted inspectors have a remit to 'promote improvement' by evaluating schools, based on pupil test results, lesson observation, questionnaires and interviews with school stakeholders (Ofsted, 2014, p. 4). Ofsted grades include: 'outstanding', 'good', 'requires improvement' and 'inadequate'. Schools not graded as 'outstanding' or 'good' are placed under the 'special measures' of further monitoring and reinspection (p. 6). Pupil achievement in high-stakes tests is key in Ofsted grading, with results upon the completion of primary education ranging from Level 3 (below average), Level 4 (average) to Levels 5 and 6 (above average). In addition to adding value 'for all pupils', measured in terms of levels on entry and on leaving the school, schools are also obliged to instil high expectations, aspirations and other 'positive' values (DfE, 2010, p. 56).

The vital importance of certain values within a well defined school culture in effecting 'continued' improvement is emphasised by the Schools White Paper 2010 (DfE, 2010, p. 51). The government White Papers set out the proposed legislation for England and are, therefore, important articulations of education policy. Specifically, the Schools White Paper 2010 cites 'positive values' as crucial in 'turning around' low performing schools (p. 56) and, conversely, 'low expectations' have been condemned as the reason for school failure (DfE, 2010; Marshall, 2013). The concept of 'continued' improvement has been constructed in education policy around three core notions of 'value'. Firstly, improvement is couched in the language of efficiency and continuing achievement of performance targets in order to deliver 'better value for money' (DfE, 2010, p. 12). Secondly, in the context of global economic competition, the value of improvement is in winning, or 'coming out on top' (Barber and Mourshed, 2007). Thirdly, 'closing the gap' between high and low achieving pupils (DfE, 2010, p.3) assigns a moral, as well as an economic value to continuous improvement.

Since the introduction of New Public Management (NPM) as a lever for public sector services reform (Mahony and Hextall, 2000), much of education policy in England has promoted values and culture change programmes which originate in the management theory and practice of business organisations. In alignment with Michael Fullan's (2001, p. 34) claim that '[r]eculturing is the name of the game', blueprints for reculturing schools have been premised on the potential of organisational culture to influence employees' values and behaviour (Hargreaves and Hopkins, 1991; Evans, 1996; Eaker et al., 2002; Senge et al., 2000). As a shared system of meaning which defines what is good/bad, desirable/non-desirable or right/wrong and establishes appropriate ways to think and behave, organisational culture helps actors to construct 
their identities, at the same time determining the nature of their obligation to others and to the organisation (Watson, 2001). Since the publication of Peters and Waterman's (1982) In Search of Excellence, excellence-culture literatures have proliferated (Watson, 2001), often on the basis of inventing new 'labels' for existing ideas (Gunter, 2004). For example, within the current focus on 'continuous improvement' in the public sector, organisations such as the Institute for Continuous Improvement in Public Services (ICiPS) claim that there is 'a change of culture going on, moving away from the old hierarchical organisations... to a new, agile, business-like public sector' (ICiPS, 2013). The binaries within this discourse imply the inferiority of the 'old' organisational hierarchies in contrast to the 'new', agile, business-like practices and values of the private sector. However, the 'new' idea of continuous improvement rehearses the familiar focus on 'strong leadership' and 'engagement of staff at all levels' in a simplistic approach to 'embedding' improvement, 'so that it is simply the way things are done' (ICiPS, 2013).

An increasing involvement of organisations such as the ICiPS in education reform is linked to New Public Management. Following Gunter and Forrester (2009, 2010), the term 'policy-makers' is used here to refer to the network of ministers, civil servants, government think-tanks, NCTL (National College for Teaching and Leadership), private-sector consultants and some advisors from local government, universities and schools. What these diverse policy-makers have in common is a neoliberal view of the school as a type of business organisation, an emphasis on the 'positivist' science of measurement and reductive conception of improvement in terms of pupil performance (Gunter and Forrester, 2009). Concurrent with their reliance on management techniques originating in the private sector, terms such as 'value for money'; 'contextual value-added'; 'vision and mission'; 'staff buying into the vision' and 'tracking pupils' entered the everyday language of school practitioners (Ball, 2008; Ball, Maguire and Braun, 2012; Gunter, 2012). As argued by Lingard and Gale (2007, p. 13), because of their 'cosmopolitan habitus', such policy ideas may impact on the global, as well as the national and the local policy discourses.

However, the underlying tensions arising from the deployment of values in reculturing schools are often neglected in the policy discourse and much of the organisational improvement literature (Gunter, 2007; Mowles, 2011). The complex and conflictual aspects of 'identity regulation' (Alvesson and Willmott, 2002) and 'identity work' (Woods and Jeffrey, 2002) have been analysed by a number of educational 
researchers (Gewirtz 2002; Vincent 2003; Ball, 2004; Busher 2006; Webb, 2009; Hammersley-Fletcher \& Qualter, 2010). This paper seeks to make a contribution to these studies by focusing on the relatively unexplored conceptualisation of 'cult' values by G. H. Mead (1914, 1923), subsequently developed further by Joas (2000), Honneth (1995) and Mowles (2011). Mead's unique insights into the dynamic and paradoxical nature of values illuminate the complexity inherent in reculturing schools and challenge the notion that embedding 'continuous improvement' is 'simply the way things are done' (ICiPS, 2013). The concept of 'cult' values refers to values which become deployed as universal, overriding group norms to which all individuals must adhere or risk exclusion, threats to identity or belonging and shame (Mead, 1923; Mowles, 2011). Based on Mead's insights, elaborated further below, this paper contends that the 'cult' of continuous improvement has emerged in the policy-makers' discourse, promoted through an inclusion/exclusion dynamic. Analysis of interview data collected in two schools illustrates how the imperative of 'continuous improvement' has been deployed in regulating primary school practitioners' values, identities and work orientations, often in conflict with their own values and understandings of 'good practice'.

\section{Values, 'cult' values and the social origins of the self}

George Herbert Mead's interest in values was prompted by the outbreak of the First World War (1914-18) and his reflection on how the death of millions of casualties seemed to be justified by the participating governments through the 'necessity' of selfdefence. As noted by Mead (1915, p. 604), the discourse on 'necessity' was accompanied by the 'appeal to the glory of combat and triumph', which masked the revival of the 'cult of Napoleon' and suppressed the reality of suffering and 'slaughter'. Mead also observed that the participating nations were spoken of 'as if' they were individuals (Griffin, 2002, p. 115). This process of individualising a collective:

\footnotetext{
... and treating it "as if" it had overriding motives and values, such as self-defence or the glorification of combat, amounted to a process in which the collective constituted a "cult". The members of such a "cult" found their behaviour being driven by the cult's values. (p. 115)
}

Mead's $(1914,1923)$ exposition of 'cult' values is rooted in his theory of the social origins of the self. The theory offers a process-based explanation of identity (the 'self'), 
which emerges through social interaction, involving the 'I', the 'me' and the 'generalised other' (Mead, 1934). The 'I' represents the emergent, spontaneous sense of self and the 'me' the sense of what others would think of the 'I':

The "I" reacts to the self which arises through the taking of the attitudes of others. Through taking those attitudes we have introduced the "me" and we react to it as an "I". (Mead, 1934, p. 174)

The 'me' constrains the 'I' and, together, they constitute two dialectical phases of the same process of the formation of the self. The social genesis of the self is premised on the individual acknowledging the attitudes of significant others, who represent the normative perspective, or the 'generalised other'. On this account, identity is not stable or fixed, but rather continuously (re)constructed through a reflective engagement with others:

The self acts with reference to others... the action with reference to the others calls out responses in the individual himself - there is then another "me" criticizing, approving, and suggesting, and consciously planning, i.e., the reflective self.

(Mead, 1913, p. 376)

That this engagement may be both harmonious and conflictual is related to the complex dynamic between the 'I', the 'me' and the 'generalised other' played out in the context of ordinary everyday interactions, in which the individual's values and sense of self ('selfidentity') need to be particularised and defined anew (Mowles, 2011). This dynamic has provided the conceptual framework for the analysis of values presented in this paper (Figure 1):

Figure 1. HERE

Figure 1 summarises the key concepts offered by Mead, which may be of help in explaining how diverse values, work orientations and identities of practitioners are influenced by the normative (and homogenising) policy discourse on continuous improvement. Mead's 'I'/'me'/'generalised other' dynamic has strong resonances with 
a more recent conceptualisation of 'self-identity' based on 'the self as reflexively understood by the person' (Giddens, 1991, p. 53). Alvesson and Willmott (2002, p. 626) emphasise the link between 'identity work' and organisational culture, whereby 'selfidentity' is reflexively constructed, 'assembled out of cultural raw material: language, symbols, sets of meanings, values... derived from countless numbers of interactions with others'. Of importance to this paper is the argument that 'self-identity' forms a 'complex... interpretive and reflexive grid gradually shaped by processes of identity regulation and identity work' (p. 626).

Three elements are crucial within the above dynamic and pertinent to the conceptual framework for the analysis of values developed in this paper (Figure 1). Firstly, Mead (1956, p. 40) emphasises relationships predicated on mutuality as vital in enabling individuals to 'enter into the attitude of others'. The purpose of such relationships is to make mutual adjustments possible, in order to develop shared understandings of 'improvement'. Mutuality would call for a continued dialogue between the policy-makers and school 'workforce', whereby 'entering into the attitude of others' is enabled through including the 'you' (in addition to the 'I'/'me'/'we'/'they') in the process (Figure 1).

Secondly, at the level of linguistic signification, Mead (1925, p. 272) emphasises the role of language ('significant symbols') in shaping the self and keeping individuals within the 'laws and axioms' of a particular 'universe of discourse'. The 'generalised other' is the censor who:

... stands at the door of our imagery and inner conversations, and in the affirmation of the laws and axioms of the universe of discourse... Our thinking is an inner conversation in which... it is with... the "generalized other" that we converse, and so attain to the levels of abstract thinking, and that impersonality, that so-called objectivity that we cherish. (Mead, 1925, p. 272)

This insight has been further elaborated by Berger and Luckmann (1966, p. 78), who explain how subjective meanings become objectified, institutionalised and eventually taken for granted as 'real', leading to the paradox of humans producing a social world which they experience as 'something other than a human product'. This understanding provides the basis for questioning the dominant version of continuous improvement defined in terms of targets for pupil performance, based on the social constructionist 
premise that ' $\mathrm{X}$ need not have existed or need not be at all as it is' (Hacking, 1999, p. 6). A discussion of the implications of this insight for alternative meanings of 'good practice' is offered later in this paper.

Thirdly, Mead's theory $(1914,1923)$ and its developments (Joas, 2000; Honneth, 1995; Mowles, 2011) point to the complex and conflictual nature of values. Defined as 'voluntary compulsions', values are paradoxical, they 'are compelling in a voluntary sense: we choose to be constrained by our values' (Mowles, 2011, p. 156). As a powerful part of our identities, values are highly individualised and imbued with strong feelings. They give our lives meaning and purpose. As emphasised by Joas (2000), values are idealisations, generalisations which need to be particularised in the contingencies of everyday living.

Consequently, the value and meaning of 'continuous improvement' cannot be established in advance, encoded in a policy and then decoded and 'bought into' by practitioners. Instead, the meaning arises in everyday work and may generate a range of responses, including compliance, resistance and conflict. A 'cult' emerges when values are set up as idealised ends or group norms, which are considered to be inviolable and which everyone has to adhere to or risk exclusion, threats to identity or shame (Mowles, 2011). In the school context, a suppression of individual values in order to adhere to an externally imposed 'cult' of improvement, may lead to a loss of meaning or a sense of belonging. As emphasised by Ball (2004, p. 9), sacrificing one's own 'commitment and experience within practice' for the sake of performance and impression may result in a 'potential 'splitting' between the teachers own judgements about 'good practice' and students 'needs' on the one hand, and the rigours of performance on the other'. A 'cult' of improvement may, therefore, erode practitioners' sense of self and self-worth.

\section{Continuous improvement in policy discourse and an inclusion/exclusion dynamic}

The continuing 'discourse of derision' (Ball, 1990), levelled at educators who question or resist the dominant approaches to reform is suggestive of the discourse of 'cult' values. This discourse has been built by successive English governments around a number of binaries, such as: 'can-do'/'moaning cynics', outstanding/mediocre, right/wrong. For example, in 1997, David Blunkett, Education Secretary for the New Labour government (1997-2010), shamed teachers who did not adopt his 'cult' of positivity as 'moaning cynics'. He issued them with the following threat: 'if you are not with us, then step aside for... [t]his is a can-do government and you must lead a can-do 
service' (Ward, 1997). In 2012, Michael Gove, a former Education Secretary for the current Coalition government, stigmatised as 'ideologues' and 'enemies of promise' practitioners who resisted his policies:

The same ideologues who are happy with failure - the enemies of promise - also say you can't get the same [test] results in the inner cities as the leafy suburbs so it's wrong to stigmatise these schools... I utterly reject that attitude. (Gove, 2012)

Similarly, the Chief Inspector of Schools, Michael Wilshaw ridiculed as 'mediocre' schools not graded as 'outstanding' or 'good' by Ofsted inspectors:

[A]lmost a third of schools in England were not judged to be good at their last inspection... I am really clear about our mission... to help ensure more of our young people get an education that is really good or outstanding, and not to tolerate what is mediocre or just satisfactory. (Wilshaw, 2012)

This inclusion/exclusion dynamic has also been deployed to reward those who comply with the policy agendas. For example, this is reflected in the current Coalition government's support for performance related pay and releasing 'outstanding schools from all routine [Ofsted] inspections' (DfE, 2010, p. 66).

The inclusion/exclusion dynamic also characterises policy-makers' discourse on pupils, either praised as 'gifted and talented' (Miliband, 2004) or objectified as the 'underperforming educational tail' (Paterson, 2013, p. 11; Marshall, 2013). For example, a New Labour government Education Secretary Estelle Morris (2002), on hearing about good PISA (Programme for International Student Assessment) results for England, emphasised that the pupils 'are a credit to themselves, their families and their schools and we should be proud of them'. Implicit in Morris's statement is the value of 'coming out on top' in international comparisons. Conversely, the Coalition government's concern about underachievement is reflected in the label of 'underperforming educational tail' assigned to the lowest achieving 20 percent of pupils in England (Marshall, 2013). The causes of 'underperformance' are identified by Marshall (2013) within two categories of cultural and socio-economic factors, with the latter including: economic disadvantage, poor quality housing, exposure to crime and anti-social behaviour. It is the 'cultural deficit', however, that is brought to the fore as a key reason 
for 'underperformance', thus contributing to the managerialist argument that the 'socalled failing schools are largely the product of poor leadership and teaching' (Gewirtz, 2002, p. xiii). 'Underperformance' is linked to the 'embedded culture of low aspiration', as well as 'complacency' on the part of teachers, local authorities and some political leaders who are reluctant to set 'aspirational' targets 'for fear of "political" criticism if the targets are not met' (Marshall, 2013, p. 13). Implicit in these arguments is a policy shift from societal (and policy) responsibility for social welfare to a deficit discourse. This makes individuals responsible for 'bettering' themselves and diminishes sociostructural barriers to the traditional assurances of the welfare state such as equality and upward mobility (Raco, 2009; Zipin et al., 2013).

As the main policy solution to 'underperformance', 'aspirational' targets may not benefit all children. Set at unrealistic levels, 'aspirational' targets may perpetuate the inclusion/exclusion dynamic. They may also be of little significance in relation to broader human needs, as strategies for raising aspiration often focus on 'instilling desire for a particular end' rather than on questions that really matter to diverse social groups (Sellar and Gale, 2011, p. 117). In this regard, Honneth (1995) has elaborated on Mead's 'I' and 'me' dialectic to posit that essential human needs of self-esteem, self-confidence and self-respect are intersubjectively acquired through the recognition of others. Conversely, a lack of recognition and denigration of one's ways of life 'injure or even destroy' a person's relation-to-self (p. 93). On this account, the denigration of the 'cultural 'blight' of low expectations' (Marshall, 2013, p. 13) is not just about exclusion through shaming, but also a misrecognition that may be damaging to the individual's sense of self-worth. This misrecognition seems to contradict the moral value attached in the Schools White Paper to 'closing the gap' between high and low achieving pupils, to eradicate 'the inequity in our system' (DfE, 2010, p. 47). As pointed out by Ball (2013, p. 93), policy discourse creates 'economies of student worth' which denigrate, brand and exclude students who do not conform to the norm or do not represent good 'value for money'. This may lead to schools trying to avoid 'costly and unproductive students those with special needs, behavioural difficulties, unsupportive parents, or another mother tongue', because they may be 'seen as threats to performance and the raising of standards' (Ball, 2013, p. 109).

When continuous improvement becomes a 'cult' and values are deployed to exclude the non-conforming self, compliance resonates with what Mead (1915, p. 605) referred to as the 'unthinking obedience of the soldier to his commander' during the First 
World War. For a nation at war, the result was the loss of 'conscious control of its own policies' (p. 605). For the school 'workforce', a culture of 'unthinking obedience' may entail an uncritical acceptance of dominant improvement schemes and suppression of alternatives. As a result, vital elements of 'good practice' may be eroded:

... in relation to oneself, one's sense of what is right; in relations with one's students, when a commitment to learning is replaced by the goals of performance; and in relations with colleagues, when struggle and debate... [are] replaced by compliance and silence. (Ball, 2004, p. 10)

\section{Research methods}

This research has aimed at exploring practitioners' understandings of their identities and narratives of everyday work in the context of continuous change engendered by education policy. Case studies of two primary schools were developed and conducted over two academic years. Data collection instruments included semi-structured 45-90 minute interviews, observation and documentary review (Stake, 2005). The specific focus of this paper is on the interplay of practitioners' and policy-makers' values ascertained from the interview data with 27 practitioners working in the schools. Practitioners who participated in this research worked in a range of roles and included: headteachers, deputy heads and senior/middle leaders (SLT); class teachers (CL); teacher assistants and pupil support staff (TA) and administrative staff (AS).

There are three cohorts of pupils in each year group in 'School A' (SA) and two in 'School B' (SB). The schools educate 'Infants' (children aged 4-6 yrs attending Reception and Year 1 - 2 classes) and 'Juniors' (aged 7 - 11 yrs, attending Year 3 - 6 classes). Both schools are located in an outer London area, have a diverse socioeconomic mix of pupils and have worked towards improved Ofsted inspection grades. At the beginning of the data collection period, School A was graded by Ofsted as 'good' and School B as 'satisfactory'. By the end of data collection (June 2012), SA received the 'outstanding' grade and SB was graded as 'good'. The case studies are thus representative of 'ordinary' schools (Maguire et al., 2011; Ball et al., 2012). Despite an original plan to include in the sample one or two schools representative of lower Ofsted grades, my attempts to gain access were unsuccessful. However, some insight into the priorities of such schools has been offered by research participants in School A and 
School B who, through previous work, had experienced 'life under special measures' (Perryman, 2006) following an 'inadequate' Ofsted grade. This issue with access could be understood as reluctance to articulate difficulties within a policy context which seems to cultivate commitment through an 'appeal to the glory of ... triumph' (Mead, 1915 , p. 604), rather than by valuing the ordinary everyday realities of working towards improvement which include both success and failure.

This paper presents findings related to data derived from three interview themes: Participants' articulations of values (Theme 2); Evaluations of changes to the government direction for education (Theme 4) and Constructs of 'school improvement' (Theme 5). In alignment with the definition of values as 'voluntary compulsions' (Mowles, 2011), questions relating to Theme 2 sought to encourage the participants to articulate their own values, before they were asked to evaluate the government direction for education. Theme 4 sought to gather data on practitioners' responses to the normative policy discourse ('involuntary compulsions'). Through its focus on the concept of 'school improvement', Theme 5 sought depth data on the participants' understandings of this concept as well as on construct convergence, by comparing the answers to all three themes. The interviews were digitally recorded, transcribed and coded using NVivo 9. Each interview was analysed in terms of construct convergence/divergence (Cresswell, 2007), content and discourse analysis (Fairclough, 2003). The codes and themes which emerged from the data were then examined in relation to concepts presented in Figure 1.

\section{Research Findings}

This paper now proceeds to discuss how the concept of continuous improvement has been (re)constructed and how it affected practitioner (self-)identities and work orientations, as articulated in the responses to interview Themes 2, 4 and 5.

\section{Values as 'voluntary compulsions'}

Understanding values as 'voluntary compulsions' (Mowles, 2011) means that diversity and individual variation can be expected when practitioners talk about their own values. In this regard, a content analysis of responses to Theme 2 revealed a range of diverse values (Table 1): 
Table 1. HERE

As can be seen from Table 1, despite the drive towards standardisation and homogeneity, values articulated by practitioners were not entirely aligned with those of the policy-makers. There was a notable convergence of values articulated by practitioners within each school, suggesting a culture of 'sharing and ambition' in School A and 'caring and responsibility' in School B. Practitioners in both schools appeared to value 'choice', linking it to autonomy, independence and responsibility. Noteworthy was also the low occurrence of 'standards', 'targets' and 'improvement' in practitioners' accounts of their own values, in contrast to the numerous references to 'standards' in response to Themes 4 and 5. Another important absence was 'citizenship' and associated values such as democracy, equality and social justice.

The content analysis (Table 1) appears to confirm Ball et al.'s (2012) point that schools are 'not of a piece'. Individual variation between practitioners working within each school also resonates with Mead's view of diverse values as an expression of our unique individuality (Honneth, 1995). Practitioners in School A particularly valued hard work, rigour, drive and rich curriculum, whilst care and work-life balance were especially valued in School B. Contrary to Marshall's (2013) reference to 'complacency' being 'most damaging' in primary schools, none of the research participants appeared complacent, on the contrary, the values of hard work and care recurred in interviews and were also 'visible' in both schools in the beautifully kept classrooms, hallways and outside areas, as well as documentary data such as children's books, work displays and other resources.

Based on the narratives of research participants who had previously worked in schools under Ofsted's 'special measures', 'complacency' did not seem to be a problem in 'struggling' schools either. Recurring in these accounts was the theme of social deprivation, with the participants referring to 'troubled families', experiencing 'enormous hardship', 'poverty', 'drug abuse', or 'mental health issues'. Improvement priorities in such schools ranged from finding money to provide food for children who came to school hungry (Angelika, SLT, SB), giving them 'wraparound care' (Emma, $\mathrm{CT}, \mathrm{SA}$ ), to managing 'children throwing chairs' in the classroom and 'very aggressive parents' in the playground (Fiona, SLT, SA). This context highlights the importance of a 'culture of care' and the recognition of the physical and emotional support necessary for 
developing children's self-confidence and self-esteem (Honneth, 1995), as the foundation for aspiration, high expectations or any other life goals.

Interestingly, the impact of 'high aspiration', constructed in the policy discourse as a prerequisite for educational success, was evaluated by participants as complex and ambiguous. For example, based on Liz's (CT, SA) experience of teaching 'Juniors' in Years 5 and 6, parental aspiration meant that secondary school transfer started for some children at the age of seven, with private tuition to prepare them for tests to selective local secondary schools. It reached a climax in Years 5 and 6:

The practice tests and [selective schools] tests go on in Year 5 and obviously they have all of their tutors... and straight away at parents' evening times we talk about different schools and different marks that they need to get... When we started in Year 6, they were having weeks off [school] for revision leading up to tests... So it's quite a lot of pressure... and then it's a knock on effect if they don't get in... (Liz, CT, SA)

During the secondary school entrance tests period, the children talk a lot about secondary school transfer and 'their anxiety levels hit the roof' (Liz). However, less than ten percent of children in School A actually secure admission to their chosen secondary schools. Simplistic notions of 'high aspiration' may not only contribute to a sense of deficit, but also trap families and children in narrow conceptions of 'bettering' themselves by outperforming others. As argued by Zipin et al. (2013, p. 4), however, life and work in the current precarious socio-economic conditions call for understanding aspiration as a process that 'also entails capacities of human agency to desire, imagine, articulate and pursue alternative futures'.

The complexities of local contexts mean that the relentless focus on academic excellence may also be unrealistic:

It is so much more difficult to get children coming from a home background where there's terrible things going on at home, and you're expected to get them to a level 4. (Jenny, SLT, SA) 
However, the policy-makers' objective of 'steering' schools 'at a distance' (Ball, Maguire and Braun, 2012, p. 73; Kickert, 1995) dismisses the importance of local contexts and diverse values, focusing instead on fostering compliance.

\section{The conforming self and narratives of 'unreflexive ease'}

The term 'unreflexive ease' has been used by Ball et al. (2012, p. 95) to refer to the 'unthinking obedience' (Mead, 1915, p. 605) with which their research participants, secondary school practitioners, enacted government policy. As suggested by the data collected in School A and School B, two processes in particular enable policy-makers to regulate the schools' workforce: Ofsted inspections and the target-setting-assessment regime. The role of Ofsted as the 'generalised other' (Mead, 1925) was revealed in the 'I'/'me' dialectic, articulated as 'them' (Ofsted) and 'us' (practitioners):

Ofsted looked upon us more favourably this time... because we've managed to maintain standards. (Stephen, SLT, SB)

Obviously we'd be doing our own evaluation... we didn't feel that we could be graded as 'satisfactory' for ourselves for a long, long time, and so it just felt: 'Oh, thank goodness!' It was a really good relief [that Ofsted graded us as 'good']. (Angelika, SLT, SB)

Ofsted plays here the symbolic function of 'others' in the formation of the school's selfimage. Ofsted inspectors construct an official account of the school, a public stamp of dis/approval which can affect the school's sense of self-worth. Practitioners in both case study schools talked about their collective effort to get a better grade at the next inspection and this included developing work orientations and monitoring systems which would 'please' the inspectors:

As well as monitoring everybody, our particular focus group is children who receive free school meals, so every class teacher has got a performance management target related to the performance and attainment of children on the free school meal register in their class... And when we had Ofsted and we showed them that was the focus group, they were really pleased with the way that we were doing it, they thought that was very good practice. (Miriam, SLT, SB) 
In praising this approach, Ofsted inspectors endorsed a practice which raises the question of equality, because it encourages teachers to privilege particular groups of children (children on the 'free school meal register' come from low income families and receive free school lunches). What has been lauded as a 'very good practice' is also based on a reductive view of 'good' teaching as 'target management'. When 'it is output that counts', teachers' own beliefs, values and commitments cease to be important (Ball, 2004, p. 10), especially under the 'seemingly omniscient gaze' of Ofsted inspectors (Perryman, 2006, p. 159).

Reductive tendencies towards 'teaching by data' seemed to be embedded in both schools through the implementation of the APP (Assessing Pupils' Progress) policy (Qualifications and Curriculum Development Agency [QCA], 2010). Accounts by practitioners responsible for assessment (Miriam, SLT, SB and Maggie, SLT, SA) suggested a 'fascination with numbers'. Maggie's role as assessment manager, responsible for monitoring the use of APP across the school, included regular 'tracking' of all children in the school, plotting graphs to map the progress of each individual child and arranging regular 'tracking meetings' with teachers to 'go through every child in a year group for maths, reading and writing'. 'Tracking' objectifies children as 'line graphs':

Some children, they sort of go like that in a straight line, so you think 'what have they done for two years?' (Maggie, SLT, SA)

The practice of 'tracking' children in order to comply with policy requirements recurred in Miriam's account of introducing APP in her school. By 'breaking down' expectations and level thresholds in writing, reading and maths, APP 'sharpened up' teachers' assessment and focused them on what Miriam referred to as the factors which constitute 'the complex child':

Some of the free school meal children were working at the lower end of their class, but they were also on the SEN register, so there was that extra factor, or some have got English as an additional language. So just to put it into context, because you just need to recognize that some children aren't just in one particular vulnerable group... So taking account of that, recognizing that there's not just one factor that 
might be affecting their learning, there might be a couple. Children are complex aren't they? (Miriam, SLT, SB)

APP encourages breaking down the 'complex child' into categories, levels and sublevels recorded in a variety of registers such as EAL (children with English as an Additional Language) and SEN (children with Special Educational Needs). Analysing, labelling and categorising children as 'vulnerable' (or not) in particular ways may lead to unequal provision, especially if children's results are linked to teachers' performance management targets. Such elaborate systems of sorting 'winners from losers' and 'top students from bottom students' are deeply corrosive of caring educational encounters (Connell, 2013, p. 106). The distortions of educational processes arising from the 'cult' of improvement in the English context may, therefore, be seen as a 'warning' to countries pursuing improvement within the paradigm of performance targets, league tables and high stakes testing (Lingard, 2010, p. 138).

From Mead's perspective, non/conformity to fixed systems of values belongs to the sphere of ethics and the individual may be 'morally required to oppose certain socially recognized values' (Joas, 1997, p. 135). For Mead, social progress is predicated on a continuing critical examination of values, which is at the same time an individual's right, obligation and basis for self-realisation. As emphasised by Joas (1997, p. 134):

The actor's self develops through consideration of the values and interests of others, and only through such consideration. In order to realize his self, the actor must therefore take part in the central conflicts and discussions about values in his society.

Paradoxically, therefore, acting 'irresponsibly', refusing to automatically respond to the continuing demands of improvement, may enable practitioners to 'take "responsibility" for the care of their selves and in doing so make clear that social reality is not as inevitable as it may seem' (Ball \& Olmedo, 2013, p. 85).

\section{The non-conforming self and reflexive unease}

In the course of talking with practitioners in both schools, I have also encountered examples of what could be referred to as 'reflexive unease'. This is because the processes of identity formation and identity regulation are ongoing, riddled with 
tensions and never complete (Honneth, 1995). Unease about school improvement policies was expressed as predominantly practical concerns about the relentless pace of change (Sandy), lack of consistency in government approaches to reform (Angelika, Maggie, Carol) and excessive amounts of paperwork linked to literacy and numeracy policies (Maria):

The constant change leaves you feeling that you don't really know what you're supposed to be doing now... And never know if you're doing the right thing or not, or where the goalposts are. (Sandy, CT, SB)

The 'half-bakedness' that has become an absolute characteristic of the government (Angelika, SLT, SB)

The last government wanted us to be looking at creative curriculum and now that we're changing, the new government say: 'We want set subjects'. (Maggie, SLT, SA)

I don't know why they change their minds so much. (Carol, AS, SB)

They've given us too much paperwork. And taken the time away from actually enjoying teaching. (Maria, CT, SA)

The reason why 'reflexive unease' was expressed mainly in relation to practical issues in everyday work, rather than more general concerns, such as a sense of one's purpose as an educator, could be because the pressure to conform to dominant values suppresses contestation and debate. As argued by Moore (2004), such a 'pragmatic turn' may be interpreted as a survival strategy in the context of intensive education reform.

'Contingent pragmatism' involves a sense of compromise, a sense of 'consciously being in a state of largely enforced adjustment' (Moore et al., 2002, p. 554).

In relation to the three core values underpinning the 'cult' of continuous improvement, concerns were articulated about 'value for money' and, specifically, the 'waste of money' engendered by continuous policy changes:

You're buying lots of stuff to back up the strategy which then becomes defunct...

So it's a waste of money, it's confusing for teachers and it's confusing for students

(Carol, AS, SB) 
Sophie (SLT, SA) questioned working to a 'business plan' rather than a school development plan and asserted that: 'we don't want to make a profit... it's not a marketplace in that sense'. Of all the participants, only Sandy (CT, SB), questioned the moral value of improvement based on competition between schools and schools' 'league tables' (tables based on pupil and school performance):

I don't really like the fact that it's all recorded in the 'league tables'... how do the schools at the bottom feel? And it's not necessarily the school's fault.

A notable pattern in the data was related to an absence of consistent contestation of education policy, despite its often 'half-baked' nature (Angelika, SLT, SB). This lack of contestation may be linked to the 'unremitting nature and speed of change required' (Hammersley-Fletcher and Qualter, 2010, p. 906). It may also originate in practitioners' reluctance to engage critically with political debates, as a result of the 'pragmatic turn' (Moore, 2004). Just four out of 27 participants referred to political issues in education and only two (Sophie, SLT, SA and Stephen, SLT, SB) contested what they perceived as ideological origins of improvement agendas. Sophie was critical of change which she perceived as based on 'party politics':

Every time you get a new government things have to be changed, regardless of whether they are working or not... I know that education has to be a political consideration, but there needs to be somewhere where things can be evaluated according to their true worth, rather than with: 'do they fit with the policies of this that or the other government.' I've got no political affiliation, I've got not much time for this to be honest... but every time we have a change of government we have to have things changed for the sake of it, because if it was the other lot's idea then can't be any good. (Sophie, SLT, SA)

Sophie's criticism of change 'for the sake of it' suggests that viewing school improvement as a political practice (Mowles, 2011) could be crucial to practitioners making a stand for their own values. Working from the premise that the dominant version of improvement 'need not be at all as it is' (Hacking, 1999, p. 6) could be a 
stimulus for re-evaluating their own practice and developing 'practices of resistance' (Ball \& Olmedo, 2013, p. 86).

\section{Inclusion/exclusion, recognition and disrespect}

The exclusions in policy-makers' discourse, reflected in the everyday practice of primary schools, were a cause concern for a small number of research participants, particularly those working in support and administrative roles. The relentless focus on test results meant success for some children and failure for others, as well as a divide between 'high' and 'low' achievers:

They've got to reach this goal, and those that don't, I feel that sometimes with their peers 'oh I've got level 3, level 4, level 5', 'I got a level 2,' and I think it can make the child that doesn't achieve as well not feel as good about themselves and as capable as those that are getting level 5, level 6'. (Sylvia, AS, SA)

According to Lynn, failure and exclusion continue after the children left their primary school:

We're quite single minded in the way we look at education, numeracy, literacy... It's great for the high achievers, it's great for those that can listen in lessons, but for those who can't, there doesn't seem to be an alternative... The few naughty kids that we do get here are disruptive because they can't do the work or they can't listen, and then when they do go to high school it just gets bigger and worse. (Lynn, TA, SA)

A poignant example of exclusion was narrated by Sandy, about a boy who was 'statemented' (children in mainstream schools in England are 'statemented' when formally identified and assessed as having severe learning difficulties):

I had a boy in my class last year statemented for speech and language, never spoke anything... I always made sure he came into the class, when before he was excluded from the class. How can you exclude someone from a classroom who's got speech and language problems? That didn't make sense to me. So I insisted that he was always there. He made us and the TAs cry once when he came up and started to talk in front of the class, and one day in maths he stood up and showed 
one of the so called 'higher ability children' how to do a maths question. (Sandy, $\mathrm{CT}, \mathrm{SB})$

These narratives presented 'minority voices' in the two schools. Underlying these accounts were practitioners' concerns about failure and exclusion, as well as their ability to enter into the attitude of the child (Mead, 1956). In wondering about the feelings of children who got 'level 2', Sylvia also implicitly questioned the value of 'coming out on top' (Barber and Mourshed, 2007). Competition creates winners and losers and the latter may perceive themselves as being of low social value, especially when education policy reinforces the high/low achievers binary and articulates disrespect through phrases such as 'the underperfoming tail' (Marshall, 2013). Feeling devalued can, in turn, lead to resistance to learning, which may account for limited progress and achievement of 'underperforming' groups of pupils (Ingram, 2009). Conversely, feeling valued is essential for self-development and self-realisation (Honneth, 1995). In the relations where adults act as the 'generalised other' (Mead, 1934), sensitivity to the need of the child to be recognised and valued should, therefore, be the overarching concern of 'good practice'. Such concern could, in turn, moderate the negative consequences of official policies (Moore, 2004).

\section{Conclusion}

In considering three key notions of value in the discourse on continuous improvement: 'value for money'; value in 'coming out on top' and moral value, this paper has turned to Mead's $(1914 ; 1923)$ theory of values to emphasise the importance of social recognition. The research findings suggest that continuing improvement and the concomitant system of rewards and sanctions foster work orientations which diminish reflexive practice.

Delivering improvement affects how practitioners see themselves as educators, leading to an endorsement of narrow conceptualisations of educational purposes. Mead's (1934) theory of the social origins of the self also points to the far-reaching implications of educational improvement conceived as meeting 'aspirational' targets for pupil performance. The target-driven conception of education appears to be focused on developing a compliant school workforce and shaping relations within schools in particular ways to serve particular interests. Claims to moral value, blended with the instrumentalist logic of 'value for money' and the value of 'coming out on top', may be deployed in education policy in order to make its predominant economic concerns more 
acceptable to practitioners. The demands on schools to add value are fostered through the inclusion/exclusion dynamic, whereby the 'glory' of high-performing schools is publically lauded and the 'mediocrity' of less successful schools publically castigated. As suggested by the case study findings, there is a tendency to enact a similar dynamic within schools in relations with children.

In the context of intensifying education reform, tensions arise between practitioners' own values and the high expectations, aspirations and 'outstanding' performance cultivated through policy. The absence of consistent contestation, however, seems to point to an ongoing shift in practitioner responses to policy from 'reflexive unease' to 'unreflexive ease' (Ball et al., 2012). As noted by Moore et al. (2002, p. 563), this shift may be indicative of a 'pragmatic turn', whereby 'contingent pragmatism', at first experienced by practitioners as 'uncomfortable', evolves into a 'desirable orientation in itself'. This, in turn, has increased a 'professional depoliticisation of teachers', leading to a situation when 'healthy educational debate including the adoption of oppositional stances - is being eroded' (p. 564). There may indeed be a 'change of culture going on' (ICiPS, 2013) in schools in England, although the 'unreflexive ease' or, to use Mead's phrase, the 'unthinking obedience' fostered through culture change programmes based on the simplistic assumption that 'sharing values is always good, while having differing values is potentially destructive' may be counter-productive (Mowles, 2011, p. 147). This is because generative possibilities inherent in diverse values are erased when a 'cult' emerges and debate and contestation are replaced by 'compliance and silence' (Ball, 2004, p. 10).

On the analysis presented in this paper, however, what appears to be an ongoing change in a particular direction is part of a complex dynamic where specific forms of identity regulation may contradict as well as reinforce the process of reculturing (Alvesson, 2002). If continuous improvement is to enhance children's education, then it will need to be based on an understanding that, as 'voluntary compulsions' (Mowles, 2011), values deployed in developing specific work orientations need to be open to debate and reflexive evaluation. The potential of values to imbue educational practice with meaning and purpose cannot be realised when meaning is imposed rather than spontaneously created. Critically, because of their inherently dynamic nature, educational values need to be defined anew, in the contingencies of educational practice in specific, local school contexts. 


\section{References}

Alvesson, M. (2002). Understanding Organizational Culture. London: Sage Publications Ltd. Alvesson, M. \& Willmott, R. (2002). Identity regulation as organizational control: Producing the appropriate individual. Journal of Management Studies, 39, 619-644.

Ball, S.J. (1990). Politics and Policy Making in Education: Explorations in Policy Sociology. London: Routledge.

Ball, S. (2004). Education reform as social Barberism: economism and the end of authenticity. Scottish Educational Review, 37, 4-16.

Ball, S.J. (2006). Education Policy and Social Class: The selected works of Stephen J. Ball. Oxon: Routledge.

Ball, S.J. (2008). New Philanthropy, New Networks and New Governance in Education. Political Studies, 56, 747-765. doi:10.1111/j.1467-9248.2008.00722.x

Ball, S.J. (2013). Foucault, Power, and Education. New York and London: Routledge.

Ball, S.J., Maguire, M. \& Braun, A. (2012). How schools do policy: Policy enactments in secondary schools. London: Routledge.

Ball, S.J. \& Olmedo, A. (2013). Care of the self, resistance and subjectivity under neoliberal governmentalities. Critical Studies in Education, 54, 85-96. doi:

10.1080/17508487.2013.740678

Barber, M. \& Mourshed, M. (2007). How the World's Best Performing School Systems Came Out On Top. McKinsey and Company.

Berger, P. \& Luckmann, T. (1966). The Social Construction of Reality: A Treatise in the Sociology of Knowledge. London: Penguin Books.

Busher, H. (2006). Understanding educational leadership: people, power and culture. Maidenhead: Open University Press.

Connell, R. (2013). The neoliberal cascade and education: an essay on the market agenda and its consequences. Critical Studies in Education, 54, 99-112. doi: 10.1080/17508487.2013.776990

Cresswell, J.W. (2007). Qualitative Inquiry \& Research Design: Choosing Among Five Approaches. London: Sage Publications Ltd.

DfE (2010). The importance of teaching: The schools' White Paper 2010. Norwich: The Stationery Office.

Eaker, R., DuFour, R. \& DuFour , R. (2002). Getting Started: Reculturing Schools to Become Professional Learning Communities. Bloomington: Solution Tree.

Evans, R. (1996). The Human Side of School Change: Reform, Resistance, and the Real-Life Problems of Innovation. San Francisco: Jossey-Bass. 
Fairclough, N. (2003). Analysing Discourse: Textual analysis for social research. Oxon: Routledge.

Fullan, M. (2001). Leading in a culture of change. San Francisco: Jossey-Bass.

Gewirtz, S. (2002). The Managerial School: post-welfarism and social justice in education. London: Routledge.

Giddens, A. (1991). Modernity and Self-Identity. Cambridge: Polity Press.

Gove, M. (2012). Who are the ideologues now? Retrieved from http://www.conservatives.com/News/Speeches/2012/01/Michael_Gove_Who_are_the_i deologues_now.aspx

Griffin, D. (2002). The Emergence of Leadership: Linking self-organisation and ethics. London and New York: Routledge.

Gunter, H.M. (2004). Labels and Labelling in the Field of Educational Leadership. Discourse: studies in the cultural politics of education, 25, 21-41. doi: 10.1080/0159630042000178464

Gunter, H.M. (2007). Remodelling the School Workforce in England: a study in tyranny. Journal of Critical Education Policy Studies, 5, 73-93.

Gunter, H.M. \& Forrester, G. (2009). School leadership and education policy-making in England. Policy Studies, 30, 495-511. doi: 10.1080/0144287090289994

Gunter, H.M. \& Forrester, G. (2010). New Labour and the logic of practice in educational reform. Critical Studies in Education, 51, 55-69. doi: 10.1080/17508480903450224

Gunter, H.M. (2012). Leadership and the Reform of Education. Bristol: The Policy Press.

Hacking, I. (1999). The Social Construction of What? Cambridge, Massachusetts: Harvard University Press.

Hammersley-Fletcher, L. \& Qualter, A. (2010). Chasing improved pupil performance: the impact of policy change on school educators' perceptions of their professional identity, the case of further change in English schools. British Educational Research Journal, 36, 903-917. doi:10.1080/01411920903215853

Hargreaves, D.H. \& Hopkins, D. (1991). The Empowered School: the management and practice of development planning. London: Cassell.

Honneth, A. (1995). The Struggle for Recognition: The Moral Grammar of Social Conflicts. Cambridge: Polity Press.

Ingram, N. (2009). Working-class boys, educational success and the misrecognition of workingclass culture. British Journal of Sociology of Education, 30, 421-434. doi:10.1080/01425690902954604

ICiPS. (2013). Continuous Improvement Conference. Retrieved from http://www.icips.org/news/98

Joas, H. (2000). The Genesis of Values. Cambridge: Polity Press. 
Joas, H. (1997). G. H. Mead: A Contemporary Re-examination of His Thought. Cambridge: The MIT Press.

Kickert, W. (1995). Steering at a distance: a new paradigm of public governance in Dutch higher education. Governance: An International Journal of Policy and Administration, 8, 135-157. doi:10.1111/j.1468-0491.1995.tb00202.x

Lingard, B. (2010). Policy borrowing, policy learning: testing times in Australian schooling. Critical Studies in Education, 51, 129-147. doi: 10.1080/17508481003731026

Lingard, B. \& Gale, T. (2007). The emergent structure of feeling: what does it mean for critical educational studies and research? Critical Studies in Education, 48, 1-23. doi:10.1080/17508480601131456

Maguire, M., Perryman, J., Ball, S. \& Braun, A. (2011). The ordinary school - what is it? British Journal of Sociology of Education, 32, 1-16. doi:10.1080/01425692.2011.527718

Mahony, P. \& Hextall, I. (2000). Restructuring Teaching: Standards, performance and accountability. London and New York: RoutledgeFalmer.

Marshall, P. (Ed.) (2013). The Tail: How England's schools fail one child in five - and what can be done. London: Profile Books.

Mead, G.H. (1914). The psychological bases of Internationalism. Survey, XIII, 604-7.

Mead, G.H. (1913). The Social Self. Journal of Philosophy, 10, 374-80.

Mead, G.H. (1923). Scientific method and the moral sciences. International Journal of Ethics, 23, 229-47. Retrieved from http://www.brocku.ca/MeadProject/Mead/pubs/Mead_1923.html

Mead, G.H. (1925). The Genesis of the Self and Social Control. International Journal of Ethics, $35,251-277$.

Miliband, D. (2004). Personalised Learning: Building a New Relationship with Schools. Retrieved from http://schools.cbe.ab.ca/b352/pdfs/PersonalizedLearning_Building.pdf

Morris, E. (2002, October 2). Full text of Estelle Morris's speech to the Labour party conference. The Guardian. Retrieved from http://www.theguardian.com/politics/2002/oct/02/labourconference.labour5

Moore, A. (2004). The good teacher: Dominant discourses in teaching and teacher education. Oxon: Routlege.

Moore, A., Edwards, G., Halpin, D., \& George, R. (2002). Compliance, resistance and pragmatism: The (re)construction of schoolteacher identities in a period of intensive educational reform. British Educational Research Journal, 28, 551-665. doi: $10.1080 / 0141192022000005823$

Mowles, C. (2011). Rethinking Management: Radical Insights from the Complexity Sciences. Farnham: Gower. 
Ofsted. (2014). The framework for school inspection. Manchester: Crown Copyright.

Paterson, C. (2013). Measuring what matters: secondary school accountability indicators that benefit all. London: CentreForum.

Perryman, J. (2006). Panoptic performativity and school inspection regimes: disciplinary mechanisms and life under special measures. Journal of Educational Policy, 21, 147161. doi:10.1080/02680930500500138

Peters, T.J. \& Waterman, R.H. (1982). In Search of Excellence. New York: Harper and Row.

Raco, M. (2009). From expectations to aspirations: State modernisation, urban policy, and the existential politics of welfare in the UK. Political Geography, 28, 436-444.

QCA. (2010). Assessing pupils' progress: learners at the heart of assessment. Retrieved from http://www.essex.gov.uk/Business-Partners/Partners/Schools/One-to-onetuition/Documents/Assessing\%20Pupil\%20Progress\%20Learners\%20at\%20the\%20hea rt\%20of\%20assessment.pdf

Sellar, S. \& Gale, T. (2011). Mobility, aspiration, voice: a new structure of feeling for student equity in higher education. Critical Studies in Education, 52, 115-134. doi: $10.1080 / 17508487.2011 .572826$

Senge, P., Cambron-McCabe, N., Lucas, T., Smith, B., Dutton, J. \& Kleiner, A. (2000). Schools that Learn: A Fifth Discipline Fieldbook for Educators, Parents, and Everyone Who Cares About Education. London: Nicholas Brealey Publishing.

Stake, R.E. (2005). Qualitative Case Studies, in N.K. Denzin \& I.S. Lincoln (Eds) The Sage Handbook of Qualitative Research ( $3^{\text {rd }}$ ed.). Thousand Oaks: Sage Publications, 443466.

Vincent, C. (2003). Introduction. In: C. Vincent (Ed.) Social justice, education and identity (pp. 1-14). London: RoutledgeFalmer.

Ward, L. (1997). Blunkett seeks unity as heads attack Woodhead, The Independent. Retrieved from http://www.independent.co.uk/news/blunkett-seeks-unity-as-heads-attackwoodhead-1264286.html

Watson, T. (2001). In Search of Management: Culture, chaos and control in managerial work. Andover: Cengage Learning.

Wilshaw, M. (2012). The end of 'satisfactory schools'. Retrieved from http://www.ofsted.gov.uk/news/ofsted-announces-scrapping-of$\%$ E2\%80\%98satisfactory\%E2\%80\%99-judgement-move-designed-help-improveeducation-for-mill

Woods, P. \& Jeffrey, B. (2002). The reconstruction of primary teachers' identities. British Journal of Sociology of Education, 23, 89-106. doi:10.1080/01425690120102872 
Zipin, L., Sellar, S., Brennan, M. \& Gale, T. (2013). Educating or Futures in Marginalized Regions: A sociological framework for rethinking and researching aspirations. Educational Philosophy and Theory, 1-20. doi:10.1080/00131857.2013.839376

Reculturing schools in England: how 'cult' values in education policy discourse influence the construction of practitioner identities and work orientations

\section{Figure 1 and Table 1}

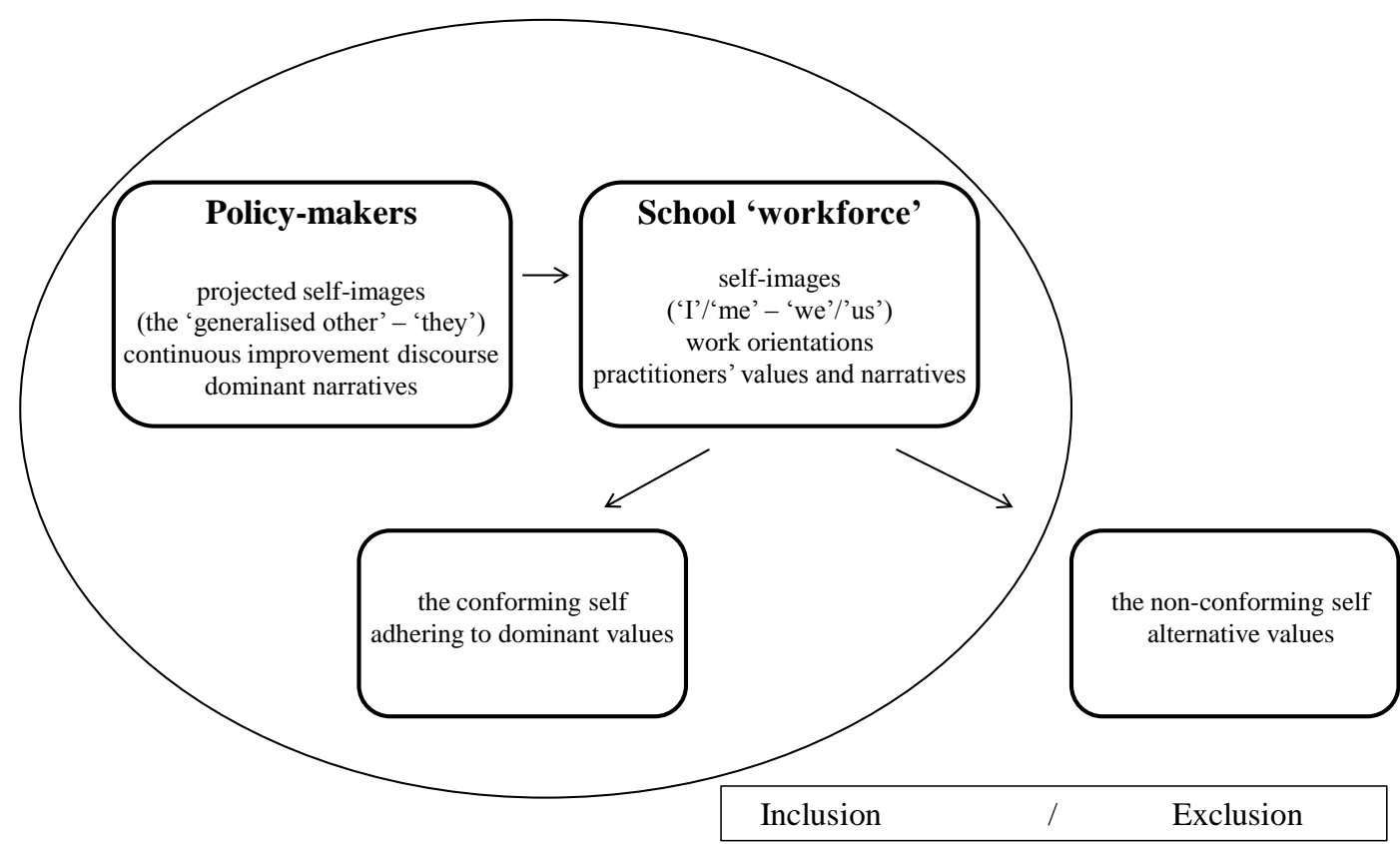

Figure 1. The normative framework for reculturing the school 'workforce'. 


\begin{tabular}{|l|l|l|}
\hline $\begin{array}{l}\text { Numbers in School A and B indicate the total number of times the } \\
\text { category was mentioned and/or elaborated on in each interview }\end{array}$ & $\begin{array}{l}\text { School A } \\
\text { (16 interviews) }\end{array}$ & $\begin{array}{l}\text { School B } \\
\text { (11 interviews) }\end{array}$ \\
\hline Ambition (rigour, drive, push, hard work, expectation) & 55 & 3 \\
\hline Choice (autonomy, responsibility, independence) & 34 & 29 \\
\hline $\begin{array}{l}\text { Enjoyment (fun, love, excitement, passion, risk taking, happy } \\
\text { children) }\end{array}$ & 17 & 19 \\
\hline 'Relational' values (respect, sharing, support, trust) & 50 & 24 \\
\hline Work-life balance (being 'comfortable') & 3 & 15 \\
\hline $\begin{array}{l}\text { Rich curriculum (including extra curricular activities and } \\
\text { events organised by the school) }\end{array}$ & 24 & 5 \\
\hline Care & 1 & 15 \\
\hline Citizenship & 0 & 2 \\
\hline Diversity (difference) & 3 & 10 \\
\hline Standards (targets, improvement) & 5 & 1 \\
\hline
\end{tabular}

Table 1. Content analysis of responses to Theme 2. 